\title{
From bread we build community: Entrepreneurial leadership and the co-creation of local food businesses and systems
}

\author{
Matthew M. Mars* \\ The University of Arizona
}

\begin{abstract}
Submitted November 2, 2014 / Revised February 10, 2015 / Accepted February 10, 2015 /
Published online May 7, 2015

Citation: Mars, M. M. (2015). From bread we build community: Entrepreneurial leadership and the co-creation of local food businesses and systems. Journal of Agriculture, Food Systems, and Community

Development, 5(3), 63-77. http://dx.doi.org/10.5304/jafscd.2015.053.005
\end{abstract}

Copyright (C) 2015 by New Leaf Associates, Inc.

\begin{abstract}
This case study of a self-described community supported baker (CSB) in Southern Arizona explores entrepreneurial leadership as a model for promoting consumer co-creation of both local food businesses and food systems. The analytical focus of the case is the entrepreneurial strategy of the CSB to embed his customers in the creation of both his community supported business and the development of a more robust Southern Arizona local food system (LFS). Specifically, the CSB's business model positions customers not only as the purchasers of his product, but also as marketers of his breads, promoters of local grains, and champions of the Southern Arizona food
\end{abstract}

* Matthew M. Mars, Ph.D., Assistant Professor, Agricultural Leadership and Communication, Department of Agricultural Education, The University of Arizona; 1110 East South Campus Drive; Saguaro Hall, Room 205; Tucson, Arizona USA 85721; +1-520-621-2239; mmars@email.arizona.edu

1 "Consumer" and "customer" are not treated as interchangeable terms. "Consumer" refers broadly to any individual who cooks with and generally eats local food. "Consumer" movement. Data was collected through a series of individual interviews with the baker and other relevant informants, as well as through multiple instances of participant observation. The case illustrates the capacity of entrepreneurial leadership to serve as a model that promotes consumer cocreation of local food businesses and more cohesive and extensive LFSs.

\section{Keywords}

entrepreneurial leadership, community supported bakery, consumer co-creation, local food systems

\section{Introduction}

Local food systems (LFSs) involve the production, distribution, and consumption of foods in ways that often directly connect producers and consum$\operatorname{ers}^{1}$ (Hinrichs, 2000). The operational models that directly connect local food producers with consumers include, for example, community supported agriculture (CSA) shares, cooperatives, farmers

\footnotetext{
emphasizes consumption without implying financial transaction. As such, the term "customer" is used to refer to individuals who specifically purchase local food products.
} 
markets, on-site sales, and roadside stands. LFSs vary from one community to another based on factors such as crop availability and diversity, delivery options, retail price tolerances, and urban versus rural settings (Patel \& MacRae, 2012; Stephenson $\&$ Lev, 2004). Productive interaction between and among producers and consumers is a key stimulant to the innovation that is required to sustain and enhance LFSs (Hinrichs, Gillespie, \& Feenstra, 2004). Unfortunately, the activities and initiatives that provide structure to LFSs are often highly fragmented. Such fragmentation causes disconnects between producers and consumers, and also promotes competition over cooperation between local food actors (growers and producers, processors, distributors, farmers market and CSA organizers, restaurateurs, retailers) that operate within shared LFSs (Hinrichs, 2000).

In this paper, I explore the entrepreneurial strategy applied by a self-described community supported baker (CSB) to help lead in the development of a cohesive Southern Arizona LFS. I rely on the conceptual constructs of entrepreneurial leadership and consumer co-creation to guide the exploration. Entrepreneurial leadership is framed as a set of strategies aimed both at increasing the financial dividends of local food entrepreneurs and bringing greater cohesion and sense of community to an otherwise fragmented and loosely identified LFS. This conceptualization of entrepreneurial leadership is consistent with other community and regional development models that are reliant upon the implementation of entrepreneurial principles and practices (see Clark, 2009; Smith, 2012; Vestrum, 2014). I also rely on the concept of value co-creation (e.g., Edvardsson, Tronvoll, \& Gruber, 2011; Grönroos \& Voima, 2013) to better understand the potential impact of direct consumer participation in the development of cohesive and welldefined local food identities on LFSs.

\section{Background}

LFS are often hampered by fragmented and loosely defined structures and relational arrangements. To counter such fragmentation, entrepreneurial strategies are sometimes relied upon to develop cooperatively based LFS supply chains (McFadden \& Marshall, 2014). For example, Marsden and Smith
(2005) described a process of "ecological entrepreneurship" whereby producers positioned along local agricultural supply chains come together to share knowledge and engage in collective innovation in order to overcome shared challenges. Similarly, Clark (2009) showed how entrepreneurial networking among local English farmers contributed to overall gains in net incomes and reductions in dependencies on state subsidies. Others have shown more recently how entrepreneurial strategies can work to bring otherwise disconnected or competing local food actors together to collectively enhance the efficiency of relevant supply chains and promote the value of local food production and consumption to community stakeholders (Hughes, Crissy, \& Boys, 2014; Matson \& Shaw, 2014; Sullins, 2014). While the implications of entrepreneurial approaches to LFS cooperation and development have been well studied, the underlying leadership required to initiate such strategies remains mostly overlooked.

Consumers are known to subscribe to loose interpretations of the meaning and value of local food, which in turn lowers their long-term commitment to local consumption (Smithers, Lamarche, \& Joseph, 2008). Such consumer "fickleness" compromises the long-term success and vibrancy of LFSs. One strategy for enhancing commitment to local foods is to embed consumers directly in the creation, implementation, and evolution of local food identities (Carey, Bell, Duff, Sheridan, \& Shields, 2011; Feagan \& Morris, 2009; Schnell, 2013). According to Guptill and Wilkins (2002), "the formation of a distinctly new kind of food system must include eaters who share in knowledgeproduction and decision-making, becoming, in other words, citizens of the food system" (p. 50). In short, direct consumer involvement in the development of local food identities is positively associated with increases in consumer commitment to local food consumption.

The strategic value of firms engaging consumers in the co-creation of markets, as opposed to positioning them only as recipients of products and services, is well documented in the management literature (e.g., Edvardsson et al., 2011; Grönroos \& Voima, 2013; Prahalad \& Ramaswamy, 2004; Vargo, Maglio, \& Akaka, 2008). The prosperity of 
businesses is directly determined by the experiences and perspectives customers accumulate over time, as well as the forecasts of their own future needs and desires (Helkkula, Kelleher, \& Pihlström, 2012). Such experience and perspective make customers uniquely equipped to be cocreators of the strategies developed and deployed by the businesses from which they purchase goods and services. In describing the strategic relevancy of co-creation, Prahalad and Ramaswamy (2004) stated, "consumers want to interact and co-create value, not just with one firm but with whole communities of professionals, service providers, and other consumers" (p. 5). In this regard, co-creation is a function of purposefully designed and managed interactions between firms and consumers (Grönroos \& Voima, 2013). Firms across a range of industries now actively work to develop and implement strategies for directly embedding consumers in strategic decision-making processes. However, no known research has been conducted that specifically focuses on the application of consumer co-creation to strategies aimed at the development of local food businesses or LFSs.

\section{Conceptual Framework}

In this paper I present a case study of the entrepreneurial leadership strategy a CSB in Southern Arizona has applied to simultaneously build his own business and develop a more cohesive local food identity and system. The CSB's entrepreneurial strategy involves embedding his customers in the co-creation of both his bakery and the broader Southern Arizona LFS. The case brings further attention to the role entrepreneurship can play in the development of robust local food environments, as well as introduce the notion of consumer co-creation to the formation of local food businesses, identities, and systems. The following six constructs of entrepreneurial leadership guide my analysis of the case: vision, perspective, influence, creativity, planning, and interaction (Cogliser \& Brigham, 2004; Fernald, Solomon, \& Tarabishy, 2005; Gupta, MacMillan, \& Surie, 2004; Kempster \& Cope, 2010).

$V$ ision refers to the capacity of leaders to construct and convey a compelling image of the intended goals and ideal outcomes associated with emergent initiatives and broader movements (Bryant, 2004; Cogliser \& Brigham, 2004). The entrepreneurial leader aspires to develop and promote a vision that compels others to invest, whether through their expertise, financial resources, reputations, social networks, or time, in the pursuit of a collective goal. Without a shared vision, the formation and advancement of a collective identity is jeopardized.

The inclusion of multiple perspectives within entrepreneurial leadership strategies expands the relevancy and strengthens the effectiveness of initiatives and broader movements. Accordingly, entrepreneurial leaders work to gain influence over a diverse set of participants and stakeholders and motivate others to collectively pursue shared goals and desired outcomes (Cogliser \& Brigham, 2004; Hogg, 2010). Accordingly, entrepreneurial leaders influence participants and stakeholders in ways that make individual needs and goals secondary to collective pursuits and shared successes.

The capacity of entrepreneurial leaders to influence individuals and motivate stakeholder groups builds over time through continuous interactions (Surie \& Ashley, 2008). Furthermore, effective entrepreneurial leaders must engage a variety of community- and professionally based learning networks and social systems (Kempster \& Cope, 2010). Regular and wide-ranging interactions increase the depth and diversity of representation embedded within entrepreneurial leadership strategies and broaden the overall appeal of initiatives and movements.

Innovation is the central to the creation of impact and a core feature of entrepreneurial leadership. Creativity inherently drives innovation (Alves, Marques, Saur, \& Marques, 2007). Hence entrepreneurial leaders draw upon creativity to formulate novel solutions aimed at positively addressing targeted problems and issues. Creativity also benefits entrepreneurial leaders while developing strategic alliances and facilitating collective action (Cogliser \& Brigham, 2004).

Lastly, entrepreneurial leadership is a relatively complex process that requires careful, continuous planning. Entrepreneurial leaders anticipate the critical points in time when resources must be allocated, as well as develop and execute action plans 
that orchestrate the activities and tasks of multiple participants and stakeholders across complex arrays of settings and environments (Sirmon \& Hitt, 2009). Entrepreneurial leaders also engage in fluid, multifaceted planning that is responsive to shifting conditions and unexpected challenges and opportunities (Brinckmann, Grichnik, \& Kapsa, 2010).

\section{Methods}

\section{Research Questions and Context}

A single case study ${ }^{2}$ of the entrepreneurial leadership strategies pursued by a self-described "community supported baker" was conducted to explore the following questions:

- How, if at all, does entrepreneurial leadership support the direct involvement of consumers in the creation of local food businesses?

- How, if at all, does entrepreneurial leadership support the direct involvement of consumers in the creation of cohesive and coherent LFSs?

\section{Case selection}

I selected the case featured in this paper using a theoretical-based sampling strategy. This strategy involves the purposeful selection of a single case (or set cases) that is directly reflective of the theoretical and/or conceptual constructs that guide a particular study (Onwuegbuzie \& Leech, 2007). Accordingly, I selected the Southern Arizona CSB as the focus of this single case study for three reasons, each of which is linked to the conceptual principles of entrepreneurial leadership and/or consumer co-creation. First, the baker is a proven entrepreneur as evidenced by having started a bakery in his two-car garage that has turned into a commercial kitchen that is now in its sixth year of operation, with an annual gross sales of US $\$ 120,000$. Second, and as described later in the paper, the baker's community-supported business model involves a high level of customer participa-

\footnotetext{
2 The design and methodology of the study were reviewed and approved by the Institutional Review Board at the university
}

tion. Third, the baker's efforts to stimulate community involvement in the development of a more cohesive and coherent Southern Arizona LFS have been widely publicized. For example, he teaches noncredit classes on the history of artisan breadmaking and its regional impact at the local university. He also regularly leads a community workshop at a regional seed bank that focuses on both bread making and the importance of heritage grains to Southern Arizona culture.

\section{Case description}

The baker described the evolution of his community supported bakery as beginning at the start of his baking career in the 1990s. He first trained as a baker in a standard retail bakery located in Northern Arizona, after completing an undergraduate degree in political science. After three years of onthe-job training, the baker started his own bakery in Northern Arizona, which was based on a standard retail business model. He closed this bakery within two years and moved to Oregon for a "change of scenery." The baker next opened a second standard retail bakery in Oregon. He closed this bakery three years after it opened because his passion for baking had waned due to the pressures of managing a growing business (e.g., employee supervision, retail contracts). The baker returned to Arizona to pursue a graduate degree in education. Following the completion of his graduate degree, he taught middle school in Tucson for nearly eight years, during which time he gained statewide recognition for teaching excellence. In 2009 he made the calculated decision to return to baking, but under a community-supported business model that he had conceptualized during his time working as a teacher.

The baker's community-supported business model involves reaching customers primarily through an online storefront from which customers order bread weekly off a rotating menu. He bakes, on average, 740 loaves of bread weekly that are purchased by about 250 customers. He distributes almost $50 \%$ of these loaves, most of which have been pre-ordered, directly to his customers at

through which the study was conducted. 
a neighborhood farmers market. This market is held every Saturday at an upscale shopping plaza located within a middle-class Tucson neighborhood. The baker selected this particular farmers market due to its close proximity to his bakery. He delivers roughly $15 \%$ of his pre-ordered bread directly to customers at a local CSA pick-up site in a working-class neighborhood in the central part of Tucson. The baker distributes $25 \%$ or so of the pre-ordered loaves directly to customers through weekly "bread days" at four public elementary schools and one private preschool. The locations of the four schools together represent lower, middle, and upper income neighborhoods located across Tucson. The customers who pick up and pay for their bread during a typical school bread day include students, parents, teachers, and surrounding neighbors.

The baker recognizes that not all his current and prospective customers will be willing and/or able to access or navigate through the online storefront. For instance, he has learned through regular interactions with his customers, many of whom he has built lasting relationships with, that the online storefront is particularly challenging for older adults. Accordingly, the baker brings extra loaves of breads that exceed the online orders to each distribution site. These loaves, which make up about $10 \%$ of weekly production (about 75 loaves) help accommodate customers without pre-orders on a "first-come, first-served" basis. Having extra loaves on hand also helps get the baker's bread in the hands of new customers (e.g., neighbors of one of the five schools who coincidently learn about the bread days when passing by or visiting the campuses), who are then directed to the online ordering site. Thus, bringing extra loaves to pick-up site acts in part as an on-the-ground marketing strategy.

The baker's rotating menu includes over 40 types of artisan breads, with three to five varieties being offered each week. The types of breads offered during a given week depend on the availability of particular types of wheat and other seasonal ingredients (e.g., locally grown basil) bought at local farmers markets. The baker would prefer to

${ }^{3}$ The SW Farm sells the bulk of the Sonoran wheat it produces online to brewers and hobby farmers located across bake all his bread using locally grown and produced ingredients. Supply scarcities, however, both in terms of variety and quantity, limit his capacity to do so. For example, he uses Sonoran wheat, which is a heritage grain that has been harvested in the Southwestern United States and Northern Mexico since at the least the $17^{\text {th }}$ century, in nearly a quarter of his breads. The baker purchases this grain directly from a local farm, which I refer to throughout this paper by the pseudonym "SW Farm." SW Farm grows mostly grows cotton and durum wheat on its 4,500 acres $(1,822 \mathrm{ha})$ of cultivated land. These crops are sold mostly to national and global manufacturers. The farm began growing Sonoran wheat as an organic crop in 2013 with the intent of bringing attention to the contributions of both small and large-scale agriculture to a Southern Arizona economy that is otherwise understood to be dependent on tourism and defense contracting. The 2013 Sonoran wheat crop was grown using 2,000 pounds $(907 \mathrm{~kg}$ ) of seeds provided by a regional seed bank with the agreement that the farm would return 4,000 pounds $(1,814 \mathrm{~kg})$ of seeds to the bank once harvesting had begun. This commitment was easily fulfilled. Currently, SW Farm is losing a marginal (but undisclosed) amount of money through its production of Sonoran wheat. However, sales are beginning to increase and profits are expected within a five-year window.

As SW Farm's largest local customer of Sonoran wheat, ${ }^{3}$ the baker purchases 75 pounds (34 $\mathrm{kg}$ ) each month at a market rate of approximately US $\$ 1.20$ per pound. The wheat has a low protein level, which limits the ability of loaves to rise during the baking process; as a result, the baker is forced to use other wheat varieties that are not grown in Southern Arizona. He sources these other grains, which make up about $75 \%$ of the grains he uses, from farms located in California, Colorado, and Utah. The baker does not have a direct relationship with any of these out-of-state farms. Instead, he shops for wheat types that are viable in terms of both price and production properties (e.g., gas production, loaf-volume response, pasting behaviors, storability). The baker has encouraged

the United States. 
the SW Farm to introduce a variety of hard red wheat to its crops. The higher proteins levels of the hard red wheat could then be used to offset the lower levels found in the Sonoran wheat. SW Farm is considering the baker's request in conjunction with the potential establishment of a local gristmill, which is discussed later in the findings.

The baker also tries as much as possible to use locally sourced ingredients purchased at local farmers markets. While the baker was unable to share the specific costs of the locally sourced products other than the Sonoran wheat, he did indicate the number of loaves he can produce that include locally sourced products is limited due mostly to price constraints. More cost-effective is the use of byproducts created during the brewing of beer (i.e., "spent grain") that the baker sources from local breweries. Regardless, the baker periodically tests the price points of his products with his customers by offering loaves that include more locally produced ingredients, but at higher prices. Based on these price point experiments, he has determined that he cannot currently increase his use of locally sourced ingredients and adequately meet consumer demand at tolerable price ranges.

\section{Data Collection}

I collected data mostly through semistructured interviews and participant observation. Specifically, I conducted four interviews lasting from one to three hours with the baker over a two-month period. I also interviewed the executive director, co-founder, education and outreach manager, and farm manager of a regional native seed bank and harvest center, as well as the founder and current director of one of the larger Southern Arizona community supported agriculture operations. Additionally, I interviewed the principal of a neighborhood public elementary school and the director of a private preschool. The elementary school under the principal's leadership and the preschool under the director's oversight both host weekly bread days. I also spoke with three representatives from SW Farms. I identified and recruited all the preceding 10 participants in this study through specific recommendations made by the baker. This recruitment strategy is consistent with the snowball sampling strategy described by Miles and Huberman
(1994). In general, the questions composing the interview protocol were designed to explore the informants' recognition and understanding of the baker's leadership in the development of the Southern Arizona LFS, as well as their perspectives on the challenges and opportunities confronting local food production and consumption in Southern Arizona.

I also called on participant observation during the data collection process. Participant observation involves researchers immersing themselves in the settings and environments within which phenomena of interest naturally occur. The primary advantage of participant observation is the ability to capture rich descriptions of the activities, behaviors, and events that are reflective of the phenomena being studied (DeWalt \& DeWalt, 2002). In discussing the importance of participant observation, DeWalt, DeWalt, and Wayland (1998) state, "living with, working with, laughing with the people that one is trying to understand provides a sense of the self and the Other that isn't easily put into words" (p. 264). In the current study, I observed and when possible participated in the production and distribution of the baker's bread on seven separate occasions. Each observation lasted between one and six hours, throughout which I carefully kept field notes. Lastly I collected and analyzed announcements and publicly available conversations posted on the baker's social media pages.

\section{Data Analysis}

I analyzed the data using both deductive and inductive approaches. Deductively, I developed and applied a structured coding framework consisting of the six entrepreneurial leadership constructs (Miles \& Huberman, 1994). This structured framework allowed for the entrepreneurial leadership strategies and practices of the baker to be revealed and thoroughly considered. I also analyzed the data using an open coding strategy in order to induce any salient patterns or trends not directly associated with the entrepreneurial leadership framework (Locke, 2001). Lastly, I compared and reconciled the themes and patterns revealed through the analysis of the data collected through the interviews, observations, and social media archives in order to 
bring greater consistency and overall trustworthiness to the findings (Patton, 2002).

\section{Limitations}

The findings of the current study are not generalizable, which is an inherent limitation of qualitative research. Accordingly the goal of the study was not to produce generalizable results. Instead, the purpose of the study was to generate new insights on how entrepreneurial leadership strategies of local food entrepreneurs might contribute to the emergence and evolution of LFSs, which include promoting the direct involvement of consumers. The reliance on a theoretically based sample-selection strategy limits the scope of the findings. Indeed, entrepreneurial leadership is not the only leadership model that likely has impact on the development of LFSs.

\section{Findings}

The baker demonstrated all six entrepreneurial leadership constructs through his approach to the production and distribution of his bread. However, I focused less on the baker's talents as an entrepreneur in the conventional sense (i.e., as a small business owner) and focused more on exploring the entrepreneurial strategy he has applied to catalyze the development of a more cohesive and coherent LFS, which includes directly involving consumers in its creation.

\section{Vision}

The baker articulated a clear vision of the economic and community conditions that he and other local food actors with whom he contracts or regularly interacts with believe are required to achieve a cohesive and coherent Southern Arizona LFS. This vision includes the development of a more robust local manufacturing system capable of more fully supporting the processing, packaging, and distribution of locally grown and raised food products. Of particular interest to the baker is the need for a local gristmill. Currently, the Sonoran wheat that is grown in Tucson by SW Farm has to be shipped 150 miles $(241 \mathrm{~km})$ north to Phoenix to be ground into flour. This extra step raises the price of the ingredient, which the baker is forced to pass on to his customers. (Recall that he has determined through interactions with customers and menu experimentation that he has reached a price point ceiling for his breads.) The baker is not the only local food actor who is affected by the costs of using Sonoran wheat, and other local ingredients for that matter. For example, he indicated that an owner of a local high-end pizzeria would like to use the heritage grain in his dough, but is unable to due to cost barriers. According to the baker, he, the pizza restaurateur, other local bakers, and the SW Farm leadership agree that establishing a local gristmill would lower the costs of production and elevate Sonoran wheat as a focal point of the Southern Arizona local food identity and system. The baker stated,

They [the local food producers] want to see grain happen here in Southern Arizona. They want to see a mill. They want to see local processing. That's what's going to tie them... there's lots going on and there's so many good people behind this we can't lose. (Anonymous, personal communication, August 26, 2014)

SW Farm leadership indicated that access to a local gristmill would further incentivize the inclusion of other specialty grains into the farm's crop production. In fact, the farm is considering hosting the mill on its property as a strategy to further develop its own local market niche and further support the overall LFS.

Momentum toward the development of a Southern Arizona gristmill has been inspired mostly by the baker's advocacy. By frequently interacting with his customers at weekly distribution sites and via his social media presence (e.g., Twitter and Facebook postings and exchanges), the baker has captured and conveyed a deep understanding of what local food consumers want and crave. Much of what he discusses with his customers is specific to their views of his breads and levels of demand for locally produced products. The insights gained through discussions with customers support the baker's advocacy of a vision for enhanced local grain production and processing capacity. This capacity in turn would help him and 
other local food actors meet market demands for local foods at accessible prices.

The baker believes the development of a complete local grain supply chain will serve as a model to motivate and guide the expansion of other Southern Arizona food sectors (e.g., produce farms, breweries, and wineries). The education and outreach manager of the regional seed bank echoed the potential downstream impact of a complete local grain supply chain on the Southern Arizona LFS and acknowledged the leadership of the baker in promoting its development. She stated, "the mill would be a true community resource. I am glad he [the baker] is involved... relocalizing means rebuilding community capacity for food processing...this is not sexy stuff that most people like to talk about (Anonymous, communication, September 29, 2014).

The baker embraces his leadership role in advancing a vision for a stronger, more complete LFS in Southern Arizona. In describing his motives for taking on such a role, he stated,

I am acting on not just my passion for my craft and my business, but also my frustration that there is so much going on here [Southern Arizona] without any synergy between those of us who are doing the work and the community who wants more local food options. We [local food actors] have talked about what we want for a long time. Now we have to act! (personal communication, August 26, 2014)

The baker is not acting alone on a vision that he has developed single-handedly. Rather, he is working closely with other local food actors and his own customers to understand, frame, and act on a shared vision of a cohesive and coherent LFS. The strategies he is using to understand, articulate, and mobilize others, including consumers and other local food actors, around a common understanding of what the Southern Arizona LFS could be is reflective of entrepreneurial vision.

\section{Perspective}

The baker recognizes the importance of remaining attentive to how those who buy his breads recognize, perceive, and value locally sourced and produced food. Using a simple flour-dusting technique during the baking process, he etches images of saguaro cacti and the Arizona state flag on the breads he makes from Sonoran wheat. These etchings are designed to remind customers of the local origins of the bread and generate discussion over the use of locally sourced ingredients. My observations of the interactions between the baker and his customers consistently revealed this strategy in practice. In describing the value of placing local production at the center of his business model and community-outreach efforts, the baker stated, "I learn something new about my product and my community every time I deliver my bread!" (personal communication, September 10, 2014).

The baker's marketing strategy is aimed both at promoting his own business and bringing community awareness and participation in developing the Southern Arizona LFS. The baker stated,

Doing everything out of the goodness of my heart is not sustainable. I also have to support my family. It is just not practical to do this kind of business and try to spark a community movement without having some financial base to grow and work from. I see no problem trying to promote my business and benefit my community. They have to go hand and hand to make a difference in the long run. (personal communication, September 10, 2014).

It would not be economically feasible for the baker to forego his business interests at the expense of being fully focused on developing a cohesive and coherent LFS. Thus, the baker has elected to pursue a two-pronged strategy that blends his business interests and the goal of bringing the perspectives of consumers more directly into the development of the Southern Arizona LFS.

The baker also uses social media to seek out customer perspectives on both his breads and the Southern Arizona local food environment. Pictures of his dough, his bakery, and his breads are posted daily as a means of bringing attention to his prod- 
uct, as well as generating community-wide discussion on the history, character, and benefits of heritage grains and other local foods. As an example, he recently included the following statement under a carefully staged photo of his bread posted on the bakery Facebook site: "If I had to make just one type of bread for the remainder of my career, it would be this one 1.5 Kilo Heritage Grain Miche” (Facebook posting, September 24, 2014). The hashtag connecting the post to other social media outlets was "\#Azwheat." This posting generated 18 follower comments regarding the flavor of the bread, preferences for various versions of the bread, and excitement over the use of locally sourced grains. Within similar posts, comments regarding the nature of the Sonoran wheat and its potential impact on the LFS are regularly discussed.

\section{Interaction}

The baker interacts with his customers with a clear purpose, which is to provide a local food experience and sense of community that is uniquely linked to Southern Arizona. Directly interacting with customers to differentiate a product from alternatives is not an uncommon business practice. However, the relationships the baker builds with his customers are not aimed just at selling his breads. Instead, customer relationships provide the baker with the opportunity to embed his customers directly in the local food narrative, which is a vital step in the process of co-creating a vibrant Southern Arizona LFS. In describing the weekly routine of distributing pre-ordered bread at a neighborhood farmers market, the baker stated,

Everyone wants to be there right at 11 o'clock when I arrive. Really if you think about it, why do they need to be there so early, because they don't. Their bread is already reserved and waiting for pick up. They're there because of the feel. They want to be there when the bread arrives and help carry it from the van to the site. They want to be part of experience. (Personal communication, September 1, 2014)

This statement helps illustrate how the baker's customers have become directly embedded in the operations of his business.

The direct interactions between the baker and his customers have become part of his and their weekly routines. The baker believes these routine interactions help the customers feel more intimately connected to the community through their local food consumption. He stated,

They [customers] want to feel the community piece. This is what helps identify them week in and week out. This becomes part of their culture, part of their tribe, part of something to belong to... I help them to see this experience as something unique to our community. Bread is a great way to help people identify with themselves, their neighbors, their community, and the local food heritage. (Personal communication, September 1, 2014)

Through his interactive business model the baker also brings a greater sense of community to the CSA where he delivers bread on a weekly basis. The director of the CSA stated, "Having the bread at the CSA is an amazing thing, because the bread has such charisma. [The baker] himself has charisma that carries through the bread. People love his bread and him!' (Anonymous, personal communication, September 11, 2014). The CSA director went on to say, "He [the baker] is a champion of Southern Arizona agriculture. He doesn't just sell his bread, he sells the whole idea of why people should care and be involved in the local production of the food we eat" (Anonymous, personal communication, September 11, 2014).

The sense of community and enthusiasm for local food developed from the community supported bakery model was regularly observed through rich and diverse interactions between customers. I regularly observed customers arriving at bread days early to help the baker set up his tables, layout table clothes, and unload his baskets of bread. In this regard, customers have voluntarily embedded themselves in the baker's operational model. The routine provided by the bread days, whether helping to set up, picking up bread, or both, allows regular customers the opportunity to 
form relationships with each other. These relationships promote discussions pertaining to family matters, health challenges, upcoming vacations, politics, etc. However, the customers also routinely shared information on other local food vendors, community events involving local food, cooking with ingredients native to the Sonoran Desert, and so on. The customers also encouraged one another to attend community events, such as a speaker series on indigenous foods that was hosted by the local university, in order to become more aware and involved in the LFS. By becoming embedded in the distribution of the bread, the bakery customers were empowered as ambassadors for both the baker's bread and the Southern Arizona LFS.

The baker brings together nearly 4,000 individuals through social media activities and campaigns. The responses to the baker's Facebook postings show that he is reaching local food actors and consumers, as well as bakers located across the country and the world who are interested in his CSB model. His posts often link to the sites and activities of other local food actors, as well as to communitysponsored events relevant to local food. For example, the baker posted a Facebook photo with the message "Beautiful Tucson evening at Tucson Meet Yourself. I will have loads of bread to sample again tomorrow $(11-4 \mathrm{pm})$. Stop by the booth at the entrance to the Library and check out the display for White Sonora Wheat" (Facebook, October 11, 2014). This post, which included a link to the SW Farm's website, was specific to a food festival designed to celebrate the overall richness and diversity of the Southern Arizona community. Such posts are not passively received. Instead, the baker uses social media posting to maintain an ongoing virtual dialogue with his followers on local food production and consumption. For example, one follower expressed her disappointment that the baker was not selected for a recent award and declared her support for local enterprise by posting, "I voted for you [the baker] and I'm disappointed to see that the winner is a corporate entity and not a local! You are by far the better choice! We'll get 'em next year!' (Facebook, January 20, 2015). Other customers commonly were observed sharing the baker's posts with others who are not already linked to the baker's site. In general, the baker uses social media both as a promotional tool for his business and those businesses run by other local food actors, and as a platform for bringing consumers together as individual and collective advocates for the development of a cohesive Southern Arizona local LFS.

\section{Influence}

There is an explicit marketing element to the outreach and education the baker provides through social media campaigning and the more intimate interactions with customers that take place during the distribution of bread. As already described, such marketing directly benefits both the baker's business and his broader efforts to lead in the development and enhancement of a cohesive and coherent LFS. The baker's pride in his product in tandem with the enthusiasm he has for further developing the LFS appears contagious. Recall the customers surrounding the baker's minivan-turneddelivery-truck to help him unload his product and set up his tables for distribution, as well as customer participation in the local food narrative via social media outlets. The baker has motivated his customers to the point that they have voluntarily become cogs in his operational model and active participants in the development and promotion of a more cohesive and coherent local food identity.

The baker's enthusiasm has also influenced the development of productive relationships between those who convene weekly at individual distribution sites. I regularly observed customers engaging in rich discussions while waiting for their bread on pick-up days. These exchanges, which in some cases span generations and backgrounds, often focus on topics specific to the bread. However, other topics relevant to local agriculture and food are also commonly discussed. Examples of such discussion topics include the benefits of purchasing local produce and foods (e.g., freshness, supporting the local economy), where to find other locally produced foods, and home remedies tied to indigenous vegetation. For instance, one customer was overheard thanking another for the recommendation to join a local CSA, which was a model of which the new member would otherwise have been unaware. Accordingly, customers have developed relationships through their routine bread pick-ups 
that have, in at least some cases, influenced one another to become more active in the broader LFS. Informal conversations had between myself and customers revealed the baker's clientele includes a balanced mix of long-time local food consumers and so-called converts who learned of the bread through word of mouth, local news stories, or as one customer put it "his [the baker's] crusade to put Tucson on the local food map!" It should also be noted that some customers who began picking up their bread at the local CSA site later joined the CSA itself as a way of becoming more involved in the LFS. These observations point to the influence the baker, albeit to a certain degree indirect, has had on customer participation in the LFS through his decision to distribute his bread at a farmers market, CSA, and on the campuses of local schools. By embedding his business within and across the community, the baker has influenced his customers to not only purchase his products, but also become more involved as active participants in the development of the Southern Arizona LFS.

\section{Creativity}

The most obvious evidence of the baker's creativity is seen through the bread he produces and the community-supported business model he has constructed. However, creativity is also made evident by the novel strategy he has implemented to help catalyze the formation of a cohesive community and coherent identity specific to local food production and consumption. Consider, for example, the baker's strategic choice to distribute bread to his customers via school campuses. This strategy positions the baker in the heart of neighborhoods where customers can conveniently pick up their freshly baked bread just beyond their doorsteps. The customers are also able to observe firsthand the learning that is taking place within the boundaries of their neighborhood school. Teachers have the opportunity to discuss educational activities and issues with community residents who otherwise would not have a reason to visit the campus. Similarly, residents are able to visit with students and strike up friendships with parents. In general, community pride is easily recognized through the various exchanges that occur on school bread days.
The director of the preschool that hosts a weekly bread day described this bridge that is created between the school and the surrounding community through the weekly bread days. She stated,

At the beginning, it was the teachers and the parents that were getting the bread. He would always give us a bag of bread for the kids to have. There's something about a community sharing bread together. There's just something really powerful about that. Now we see that the whole neighborhood's onto it and they're lining up together to wait for the bread. (Anonymous, personal communication, September 29, 2014)

The infusion of education into the baker's supply chain has proven to be a creative, highly effective strategy for simultaneously developing a community-supported business and supporting the community through local food production and consumption. This approach of embedding education into the operational model of the bakery creates both economic and social value. Economically, the school bread days provide a distribution point for the baker and a convenient purchasing location for customers. Socially, school bread days provide a creative mechanism for enhancing agriculture and food literacy among children, building a local food identity, and further connecting customers to their community.

When asked to label his professional identity by title, the baker responded, "I am mostly a baker and social entrepreneur. I want to build my community and promote its heritage and local identity through my bread! But I also see myself as an artist, scientist, and educator." This self-identification by the baker was reflected in the following hash tags that accompanied a social media photo post of his bread: "feedyourcommunity," "communityservice," and "socialentrepreneur." Creativity is a common thread that weaves through all of these self-identified roles and further characterizes the baker as an entrepreneurial leader within the Southern Arizona LFS.

\section{Planning}

The baker has been very intentional in his efforts 
to not only create a viable business, but also to promote and lead in the development of a synergist LFS in Southern Arizona. He described the Southern Arizona LFS as "lacking synergy and having very little sense of community and common identity. How can someone get excited about something they can't see or understand? I want a food environment that helps my business and makes the community I live in stronger" (personal communications, September 10, 2014). Moreover, the baker indicated that his decision to leave a distinguished teaching career and return to baking was planned. He stated, "I gave myself eight years to be a teacher and plan out my community supported baking model. I knew I would return to baking, but in a way that allowed me to work more freely and to be directly involved in my community" (personal communication, August 26, 2014). These two comments illustrate how the baker's business strategy and community leadership activities are being guided by an overall plan that is anchored in both personal ambition and a strong sense of citizenship.

The baker consistently demonstrates a clear strategy for achieving the long-term vision he and other local food actors and consumers have for a cohesive, vibrant Southern Arizona LFS. The cofounder of the regional seed bank, who is also a long-time local agriculture activist, emphasized the importance of the baker's role in the planning and development of the Southern Arizona LFS. He stated, "[the baker] is linchpin in the LFS. He has a way of connecting all kinds of otherwise disconnected people together to support local agriculture and food. Without him mapping out for us where we all think we should be going, much less would be happening!" (Anonymous, personal communications, December 22, 2014). This statement points to the importance of local food communities having leaders who can not only capture a diverse range of perspectives and recognize and articulate a shared vision, but also lead in the creation and implementation of a plan to act on that vision.

\section{Discussion and Conclusion}

The baker's activities and strategies demonstrate the processes of entrepreneurial leadership and customer co-creation on two levels. At the business level, he purposefully embeds his customers within his community-supported business model. In doing so, he has built a loyal customer base that enthusiastically promotes his bread through word of mouth and social media postings, as well as voluntarily helps him operate his business. At the community level, the baker strategically embeds his customers in conversations and initiatives that promote the development of the Southern Arizona LFS. These conversations and initiatives are otherwise fragmented and involve only local food actors. Moreover, the baker creates opportunities to educate his customers on the value of locally grown and processed grains in an effort to grow and demonstrate the market demand necessary to expand the processing capacity of the Southern Arizona LFS (e.g., the installation of a local gristmill). He believes that showing market demand through customer advocacy will compel the SW Farm and other local food actors to invest individually or cooperatively in a mill. If this strategy proves effective, the baker expects his costs will decrease and his production of "local loaves" will increase

Customers helping to unload the baker's breads and set up his display tables generate few, if any, financial benefits. However, the weekly "work" routine makes customers feel more connected to the baker and his bread, as well as to the broader local food environment. Recall that customer loyalty to local food consumption has been shown to wax and wane based on uncertainties in the scope and importance of LFSs (Smithers, Lamarche, \& Joseph, 2008). Thus, approaches such as the baker's to embed customers directly within the operations of local food businesses may prove to be an effective strategy in building consumer commitment to local food consumption. More specifically, the creation of opportunities for consumers to be active in the creation of local food enterprise and systems may prove more effective than passive strategies aimed at education and the promotion of guilt-driven purchases.

Untangling the business- and communitybased agendas that underpin the baker's entrepreneurial leadership is not possible. Indeed, one agenda rests upon the other. Without acting in the 
best interest of his business, the baker's capacity to influence the development and growth of a cohesive and more extensive LFS would be stunted, if not completely blocked. A more extensive LFS that supports the scaling of locally based production and processing capacities is needed if the baker is to scale his own production of breads made from local grains. Moreover, a loyal customer base that is inspired to become more active in the development of the Southern Arizona LFS is consistent with the baker's vision for his business, the local food environment, and his community as a whole. Future research on the multiple value propositions that can be nurtured through customer co-creation and the blending of entrepreneurial agendas that are market-facing and community-oriented are recommended.

One local food entrepreneur with a specific focus (e.g., bread and local grains) is unlikely to be able to singlehandedly lead in the co-creation of a LFS. Instead, networks of local food actors who recognize the collective promise of a communitywide customer base that is deeply immersed and committed to their LFSs should be formed and nurtured. These networks are not likely to emerge organically. Local food advocates and organizations, such as farmers market organizers and Cooperative Extension agents, are encouraged to bring local food actors together to develop a systemwide strategy for embedding consumers directly into the development and operations of LFSs. The entrepreneurial leadership constructs can together be a functional guide to creating such systemic cocreation strategies that are compelling to multiple actors based on the potential benefits to both individual businesses and broader LFSs. Furthermore, community organizations not otherwise directly linked to the LFSs should also be integrated into systemwide co-creation strategies. The baker's use of local schools as distribution sites illustrates this broader notion of "community co-creation." The school bread days simultaneously support the bakery, build community, encourage experiential learning, and promote the value of local food production and consumption. Each LFS has its own set of unique characteristics and community-based assets that should be holistically assessed with the goal of creating LFS networks of diverse and otherwise disconnected organizations.

Additional research that examines the impact of customer co-creation on local food businesses, identities, and systems is needed. Specific questions that warrant attention include: Does consumer loyalty to local food production and consumption increase through co-creation? Does the co-creation of local food businesses and systems increase investment behaviors through unconventional funding models (e.g., crowdfunding)? Does co-creation contribute to the further development and enhancement of the supply chains that help underpin LFSs? These questions should not be limited to the academic domain. Instead, local food leaders, such as Extension agents, local and regional development officers, and board members of relevant nonprofit organizations, are encouraged to track such questions throughout co-creation processes.

\section{Acknowledgments}

The author would like to thank Dr. Hope Schau and Don Guerra for the support and feedback they provided throughout the various iterations of this paper.

\section{References}

Alves, J., Marques, M. J., Saur, I., \& Marques, P. (2007). Creativity and innovation through multidisciplinary and multisectoral cooperation. Creativity and Innovation Management, 16(1), 27-34. http://dx.doi. org/10.1111/j.1467-8691.2007.00417.x

Brinckmann, J., Grichnik, D., \& Kapsa, D. (2010). Should entrepreneurs plan or just storm the castle? A meta-analysis on contextual factors impacting the business planning-performance relationship in small firms. Journal of Business Venturing, 25(1), 24 40. http://dx.doi.org/10.1016/i.jbusvent.2008. $\underline{10.007}$

Bryant, T. A. (2004). Entrepreneurship. In G. R. Goethals, G. J. Sorensen, \& J. M. Burns (Eds.), Encyclopedia of leadership (Vol. 1, pp. 442-448). Thousand Oaks, California: SAGE.

Carey, L., Bell, P., Duff, A., Sheridan, M., \& Shields, M. (2011). Farmers' market consumers: A Scottish perspective. International Journal of Consumer Studies, 35(3), 300-306. http://dx.doi.org/10.1111/j.1470$\underline{6431.2010 .00940 . \mathrm{x}}$ 
Clark, J. (2009). Entrepreneurship and diversification on English farms: Identifying business enterprise characteristics and change processes.

Entrepreneurship \& Regional Development: An International Journal, 21(2), 213-236. http://dx.doi.org/10.1080/08985620802261559

Cogliser, C. C., \& Brigham, K. H. (2004). The intersection of leadership and entrepreneurship: Mutual lessons to be learned. The Leadership Quarterly, 15(6), 771-799. http://dx.doi.org/10.1016/j.leaqua.2004.09.004

DeWalt, K. M., \& DeWalt, B. R. (2002). Participant observation: A guide for fieldworkers (2 ${ }^{\text {nd }} \mathrm{Ed}$.). Walnut Creek, California: AltaMira Press.

DeWalt, K. M., DeWalt, B. R., \& Wayland, C. B. (1998). Participant observation. In H. R. Bernard (Ed.), Handbook of Methods in Cultural Anthropology (pp. 259-300). Walnut Creek, California: AltaMira Press.

Edvardsson, B., Tronvoll, B., \& Gruber, T. (2011). Expanding understanding of service exchange and value co-creation: A social construction approach. Journal of the Academy of Marketing Science, 39(2), 327339. http://dx.doi.org/10.1007/s11747-010-0200-y

Feagan, R. B., \& Morris, D. (2009). Consumer quest for embeddedness: A case study of the Brantford Farmers' Market. International Journal of Consumer Studies, 33(3), 235-243. http://dx.doi.org/10.1111/ j.1470-6431.2009.00745.x

Fernald, L. W., Jr., Solomon, G. T., \& Tarabishy, A. (2005). A new paradigm: Entrepreneurial leadership. Southern Business Review, 30(2), 1-10.

Grönroos, C., \& Voima, P. (2013). Critical service logic: Making sense of value creation and co-creation. Journal of the Academy of Marketing Science, 41(2), 133150. http://dx.doi.org/10.1007/s11747-012-0308-3

Gupta, V., MacMillan, I. C., \& Surie, G. (2004). Entrepreneurial leadership: Developing and measuring a cross-cultural construct. Journal of Business Venturing, 19(2), 241-260. http://dx.doi.org/10.1016/S0883-9026(03)00040-5

Guptill, A., \& Wilkins, J. L. (2002). Buying into the food system: Trends in food retailing in the US and implications for local foods. Agriculture and Human Values, 19(1), 39-51. http://dx.doi.org/10.1023/A:1015024827047

Helkkula, A., Kelleher, C., \& Pihlström, M. (2012). Characterizing value as an experience: Implications for service researchers and managers. Journal of Service Research, 15(1), 59-75. http://dx.doi.org/10.1177/1094670511426897

Hinrichs, C. C. (2000). Embeddedness and local food systems: Notes on two types of direct agricultural markets. Journal of Rural Studies, 16(3), 295-303. http://dx.doi.org/10.1016/S0743-0167(99)00063-7

Hinrichs, C. C., Gillespie, G. W., \& Feenstra, G. W. (2004). Social learning and innovation at retail farmers' markets. Rural Sociology, 69(1), 31-58. http://dx.doi.org/10.1526/003601104322919892

Hogg, M. A. (2010). Influence and leadership. In S. T. Fiske, D. T. Gilbert, \& G. Lindzey (Eds.). Handbook of Social Psychology (5 ${ }^{\text {th }}$ Ed., Vol. 2; pp. 1166-1206).

New York: Wiley. http://dx.doi.org/10.1002/ 9780470561119.socpsy002031

Hughes, D. W., Crissy, H., \& Boys, K. (2014). Limehouse Produce: A unique wholesaler of locally sourced produce. Journal of Food Distribution Research, 45(3), 58-67. http://purl.umn.edu/190896

Kempster, S., \& Cope, J. (2010). Learning to lead in the entrepreneurial context. International Journal of Entrepreneurial Behavior \& Research, 16(1), 5-34. http://dx.doi.org/10.1108/13552551011020054

Locke, K. (2001). Grounded theory in management research. Thousand Oaks, California: SAGE.

Marsden, T., \& Smith, E. (2005). Ecological entrepreneurship: Sustainable development in local communities through quality food production and local branding. Geoforum, 36(4), 440-451. http://dx.doi.org/10.1016/j.geoforum.2004.07.008

Matson, J., \& Shaw, J. (2014). Sandhills Farm to Table. Journal of Food Distribution Research, 45(3), 26-34. http://purl.umn.edu/190893

McFadden, D. T., \& Marshall, M. I. (2014). Local food systems and interactions with entrepreneurship [Editor's introduction]. Journal of Food Distribution Research, 45(3), 1-3. http://purl.umn.edu/190651

Miles, M. B., \& Huberman, A. M. (1994). Qualitative data analysis (2nd Ed.). Thousand Oaks, California: SAGE.

Onwuegbuzie, A. J., \& Leech, N. L. (2007). A call for qualitative power analyses. Quality and Quantity, 41(1), 105-121. http://dx.doi.org/10.1007/s11135005-1098-1

Patel, S., \& MacRae, R. (2012). Community supported agriculture in the city: The case of Toronto. Journal of Agriculture, Food Systems, and Community Development, 2(4), 85-100. http://dx.doi.org/10.5304/jafscd.2012.024.003 
Patton, M. Q. (2002). Qualitative research \& evaluation methods. Thousand Oaks, California: SAGE.

Prahalad, C. K., \& Ramaswamy, V. (2004). Co-creation experiences: The next practice in value creation. Journal of Interactive Marketing, 18(3), 5-14. http://dx.doi.org/10.1002/dir.20015

Schnell, S. (2013). Food miles, local eating, and community supported agriculture: Putting local food in its place. Agriculture \& Human V alues, 30(4), 615-628. http://dx.doi.org/10.1007/s10460-013$\underline{9436-8}$

Sirmon, D. G., \& Hitt, M. A. (2009). Contingencies within dynamic managerial capabilities: Interdependent effects of resource investment and deployment on firm performance. Strategic Management Journal, 30(13), 1375-1394. http://dx.doi.org/10.1002/smj.791

Smith, R. (2012). Developing and animating enterprising individuals and communities: A case study from rural Aberdeenshire, Scotland. Journal of Enterprising Communities: People and Places in the Global Economy, 6(1), 57-83.

http://dx.doi.org/10.1108/17506201211211000

Smithers, J., Lamarche, J., \& Joseph, A. E. (2008). Unpacking the terms of engagement with local food at the farmers' market: Insights from Ontario.
Journal of Rural Studies, 24(3), 337-350. http://dx.doi.org/10.1016/j.jrurstud.2007.12.009

Sullins, M. (2014). Zia Taqueria: Building local supply chain in Southwestern Colorado. Journal Food Distribution Research, 45(3), 13-25. http://purl.umn.edu/191005

Surie, G., \& Ashley, A. (2008). Integrating pragmatism and ethics in entrepreneurial leadership for sustainable value creation. Journal of Business Ethics, 81(1), 235-246. http://dx.doi.org/10.1007/s10551007-9491-4

Stephenson, G., \& Lev, L. (2004). Common support for local agriculture in two contrasting Oregon communities. Renewable Agriculture and Food Systems, 19(4), 210-217. http://dx.doi.org/10.1079/RAFS200481

Vargo, S. L., Maglio, P. P., \& Akaka, M. A. (2008). On value and value co-creation: A service systems and service logic perspective. European Management Journal, 26(3), 145-152. http://dx.doi.org/10.1016/j.emj.2008.04.003

Vestrum, I. (2014). The embedding process of community ventures: Creating a music festival in a rural community. Entrepreneurship \& Regional Development: An International Journal, 26(7-8), 619-644. http://dx.doi.org/10.1080/08985626.2014.971076 